\title{
PENGARUH PENGgGUNAAN ALAT PERAGA PAPAN PERSAMAAN LINIER SATU VARIABEL (PLSV) TERHADAP HASIL BELAJAR SISWA PADA MATERI SISTEM PERSAMAAN LINIER SATU VARIABEL DI SMPN 2 PANJI TAHUN PELAJARAN 2019/2020
}

\author{
Ye s i Puspitasari,S.Pd,M.Si ${ }^{1}$, Irma Noervadila,S.Pd,M.Pd ${ }^{2}$, Siti Fatimah $^{3}$ \\ ${ }^{1,2,3}$ STKIP PGRI Situbondo, Situbondo \\ email:1 ${ }^{1}$ esipuspita31@gmail.com, 2 noervadilairma@gmail.com, \\ ${ }^{3}$ sitifhatiemah@gmail.com
}

Received: May 31, 2020

Revised: June 3, 2020

Accepted: June 6, 2020

\begin{abstract}
Abstrak
Matematika merupakan mata pelajaran yang bersifat abstrak sehingga membutuhkan penalaran tinggi untuk memahaminya. Alat peraga papan persamaan linier satu variabel (PLSV) merupakan alat peraga yang digunakan untuk materi sisitem persamaan linier satu variabel. Hasil belajar merupakan perubahan yang terjadi pada diri siswa, baik yang menyangkut aspek kognitif, afektif, dan psikomotor sebagai hasil dari kegiatan belajar. Tujuan penelitian untuk mengetahui adakah pengaruh penggunaan alat peraga papan persamaan linier satu variabel (PLSV) terhadap hasil belajar siswa pada materi sistem persamaan linier satu variabel di SMP Negeri 2 Panji tahun pelajaran 2019/2020. Penelitian ini merupakan jenis penelitian ini kuantitatif dengan metode Quasi Eksperimen Semu.Teknik pengumpulan data dengan menggunakan tes dan dokumentasi. Data yang diperoleh dari hasil tes dianalisis melalui uji validitas, uji reliabilitas dan uji hipotesis. Berdasarkan hasil penelitian ini diperoleh $\mathrm{t}$ hitung $=2,088$ dan $\mathrm{t}$ tabel $=2,000$. Karena $\mathrm{t}$ hitung $>\mathrm{t}$ tabel $(2,088>2,000)$ dengan demikian $\mathrm{H} 0$ ditolak dan Ha diterima. Sementara perhitungan rata-rata nilai post tes kelas eksperimen sebesar 82,5625 sedangkan rata-rata nilai post tes kelas kontrol sebesar 78,25
\end{abstract}

Kata Kunci: Alat peraga, Hasil belajar siswa, Matematika

\section{Abstract}

Mathematics is an abstract subject that requires high reasoning to understand it. One variable linear equation board (PLSV) teaching aids are teaching aids used for one variable linear equation system material. Learning outcomes are changes that occur in students, both those related to cognitive, affective, and psychomotor aspects as a result of learning activities. The purpose of this research is to find out whether there is an influence of the use of one-variable linear equation board props (PLSV) on student learning outcomes in the material of the linear one-variable equation system in SMP Negeri 2 Panji in the academic year 2019/2020. This research is a quantitative type of research with Quasi Experimental Method. Data collection techniques using tests and documentation. Data obtained from the test results are analyzed through validity, reliability and hypothesis testing. Based on the results of this study obtained $t$ count $=2.088$ and $t$ table $=2,000$. Because $t$ count $>t$ table $(2,088>2,000)$ thus $\mathrm{HO}$ is rejected and Ha is accepted. While the calculation of the average value of the post-test experimental class is 82.5625 while the average post-test control class value is 78.25 .

Keywords: teaching aids, student learning outcomes, Matematicts 


\section{PENDAHULUAN}

Pendidikan ialah usaha menumbuh kembangkan sumber daya manusia melalui kegiatan pembelajaran (Susanto, 2013).Kegiatan pembelajaran tersebut diselenggarakan pada semua satuan atau jenjang pendidikan.Pembelajaran sebagai aktivitas operasional kependidikan yang dilaksanakan oleh guru yang tugas utamanya mengajar. Untuk mengatasi kesulitan siswa dalam belajar matematika seorang guru harus mengupayakan inovasi dalam pembelajaran agar tumbuh kembali minat dan perhatian siswa untuk mempelajari matematika, sehingga hasil belajar siswa dalam matematika di SMPN 2 Panji, terutama pada penggunaan alat peraga papan persamaan linier satu variabel (PLSV) maksimal. Penggunaan alat peraga merupakan salah satu inovasi pembelajaran untuk membantu siswa memahami materi matematika.

Menurut Annisah (2014), Media pembelajaran merupakan alat yang dapat membantu proses belajar mengajar dan berfungsi untuk memperjelas makna pesan yang disampaikan, sehingga dapat mencapai tujuan pembelajaran dengan lebih baik dan sempurna. Media pembelajaran merupakan sarana untuk meningkatkan kegiatan proses belajar mengajar.

Mengingat banyaknya bentuk-bentuk media tersebut, maka guru harus dapat memilihnya dengan cermat, sehingga dapat digunakan dengan tepat. Pembelajaran dengan menggunakan alat peraga papan persamaan linier satu variabel (PLSV) di SMPN 2 Panji membantu memantapkan pengetahuan di benak para siswa serta menghidupkan proses pembelajaran di dalam kelas dengan alat peraga papan persamaan linier satu variabel (PLSV). Salah satu alat peraga yang berhubungan dengan konsep sistem persamaan linier satu variabel yang akan dibahas dengan menggunakan alat peraga papan persamaan linier satu variabel (PLSV).

\section{METODE PENELITIAN}

Dari paparan diatas peneliti berasumsi bahwa ala peraga papan persamaan linier satu variabel (PLSV) mempengaruhi hasil belajar siswa di SMP Negeri 2 Panji Tahun Pelajaran 2019/2020. Dalam penelitian ini menggunakan rancanganmenggunakan metode kuantitatif yang bersifat Quasi Eksperimen Semu. Desain penelitian eksperimen yang digunakan dalam penelitian ini berbentuk Nonequivalent Control Group Design.Dalam penelitian ini peneliti hanya menggunakan posttest atau tes akhir setelah diberikan perlakuan pada kelas eksperimen maupun kelas kontrol.

Teknik penentuan responden penelitian ini menggunakan teknik nonprobability samplingyaitu populasinya seluruh siswa kelas VII SMP Negeri 2 Panji. Sedangkan sampel yang digunakan sebanyak 2 kelas yaitu kelas VII A dan B yang terdiri 64 siswa dari 120 populasi. 
Teknik pengumpulan data dengan menggunakan tes dan dokumentasi.Tes dilaksanakan setelah siswa diberi perlakuan yaitu kelas eksperimen diberi perlakuan dengan menggunakan alat peraga dan kelas kontrol diberi perlakuan tanpa menggunakan alat peraga.

Untuk mengetahui tingkat kecerdasan siswa sebelum perlakuan, data diambil dari nilai ujian tengah semester (UTS).

Teknik analisis data dalam penelitian ini menggunakan uji validitas, uji reliabilitas dan uji-t.Data merupakan unsur mutlak dalam penelitian, yang mana data tersebut masih harus di analisis menggunakan teknik tertentu yang sesuai dengan sifat data. Meskipun langkah-langkah penelitian dilakukan dengan baik, tetapi jika analisis datanya salah atau tidak relevan maka kesimpulan yang didapat tidak bisa di pertanggung jawabkan.Mengingat hasil yang diperoleh dari penelitian ini berupa angka - angka atau data kuantitatif maka peneliti menggunakan metode statistic.

\section{HASIL DAN PEMBAHASAN}

Hasil data Nilai Ujian Tengah Semester Kelas Eksperimen dan kelas control digunakan untuk mengetahui nilai sebelum perlakuan. Adapun hasil dari data tersebut dapat dilihat pada tabel berikut ;

Tabel 1. Distribusi Ujian Tengah Semester Kelas Eksperimen

\begin{tabular}{cc}
\hline Kelas Interval & Frekuensi \\
\hline $45-50$ & 3 \\
\hline $51-56$ & 3 \\
\hline $57-62$ & 10 \\
\hline $63-68$ & 6 \\
\hline $69-74$ & 8 \\
\hline $75-80$ & 2 \\
\hline Jumlah & 32 \\
\hline
\end{tabular}

Frekuensi nilai tertinggi siswa kelas eksperimen terdapat pada rentang nilai 57 - 62 yaitu sebanyak 10 siswa dan frekuensi terendah terdapat pada rentang nilai 75 - 80 yaitu sebanyak 2 siswa. Kemampuan siswa dalam pelajaran matematika sebelum diberi perlakuan menggunakan alat peraga dapat dilihat dari histogram nilai Ujian tengah semester (UTS) kelas eksperimen. 


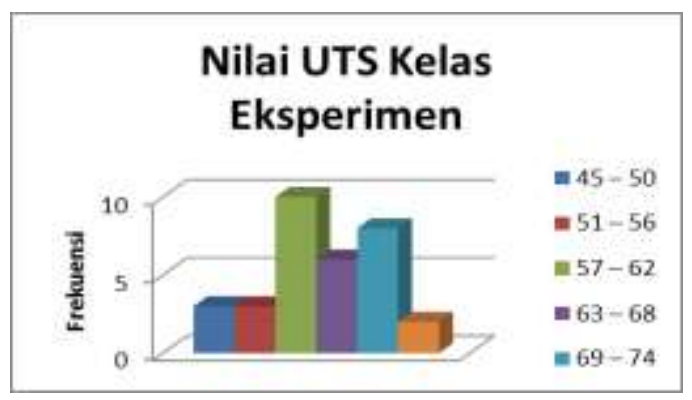

Gambar 1. Nilai Ujian Tengah Semester (UTS) kelas Eksperimen

Tabel 2. Distribusi Nilai Ujian Tengah Semester (UTS) Kelas Kontrol

\begin{tabular}{cc}
\hline Kelas Interval & Frekuensi \\
\hline $45-52$ & 3 \\
\hline $53-60$ & 4 \\
\hline $61-68$ & 14 \\
\hline $69-76$ & 3 \\
\hline $77-84$ & 6 \\
\hline $85-93$ & 2 \\
\hline Jumlah & 32 \\
\hline
\end{tabular}

Frekuensi nilai tertinggi siswa kelas kontrol terdapat pada rentang nilai 61 - 68 yaitu sebanyak 14 siswa dan frekuensi nilai terendah terdapat pada rentang nilai 85-93 yaitu sebanyak 2 siswa.

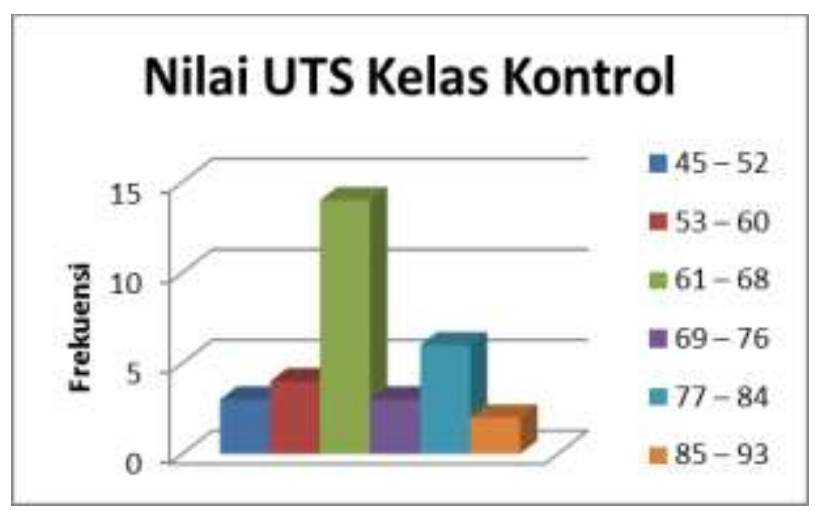

Gambar 2. Histogram Nilai Ujian Tengah Semester (UTS) Kelas Kontrol

Data Hasil Belajar Siswa post test diperoleh dari nilai ulangan harian setelah mengikuti pelajaran matematika pada materi sistem persamaan linier satu variable pada kelas Eksperimen dan Kelas Kontrol sebagai berikut; 
Tabel 3. Distribusi Post test Kelas

Eksperimen

\begin{tabular}{cc}
\hline Kelas Interval & Frekuensi \\
\hline $65-69$ & 2 \\
\hline $70-74$ & 1 \\
\hline $75-79$ & 6 \\
\hline $80-84$ & 10 \\
\hline $85-89$ & 6 \\
\hline $90-94$ & 6 \\
\hline $95-99$ & 1 \\
\hline Jumlah & 32 \\
\hline
\end{tabular}

Hasil post test kelas eksperimen diperoleh frekuensi nilai tertinggi siswa terdapat pada rentang nilai $80-84$ yaitu sebanyak 10 siswa dan frekuensi terendah terdapat pada rentang nilai 75 - 79 yaitu sebanyak 1 siswa serta pada rentang nilai 95 - 99 sebanyak 1 siswa.

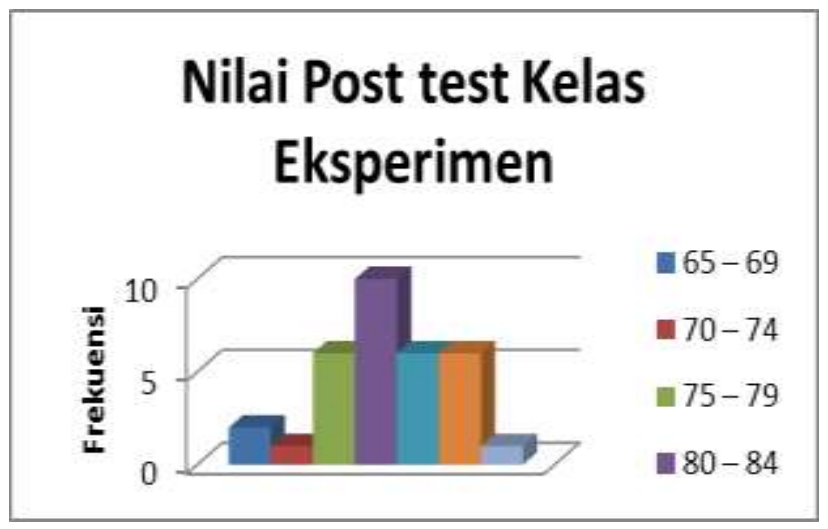

Gambar 3. Histogram Nilai Post test Kelas Eksperimen
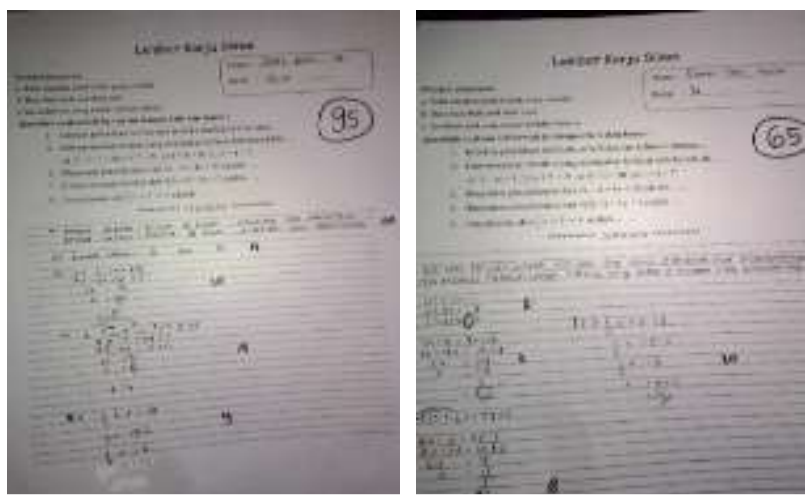

Gambar 4. Nilai Post test tertinggi dan terendah Kelas Eksperimen

Data post test diperoleh dari nilai ulangan harian setelah mengikuti pelajaran matematika pada materi sistem persamaan linier satu variable kelas kontrol 
Tabel 4. Distribusi Post test Kelas Kontrol

\begin{tabular}{cc}
\hline Kelas Interval & Frekuensi \\
\hline $65-69$ & 2 \\
\hline $70-74$ & 1 \\
\hline $75-79$ & 6 \\
\hline $80-84$ & 6 \\
\hline $85-89$ & 6 \\
\hline $90-94$ & 1 \\
\hline $95-99$ & 32 \\
\hline Jumlah & 6 \\
\hline
\end{tabular}

Frekuensi nilai tertinggi siswa terdapat pada rentang nilai $74-80$ yaitu sebanyak 10 siswa dan rentang nilai 81 - 94 sebanyak 10 siswa. Frekuensi nilai terendah terdapat pada rentang nilai 88 - 94 yaitu sebanyak 2 siswa. Berikut ini histogram nilai post test kelas control;

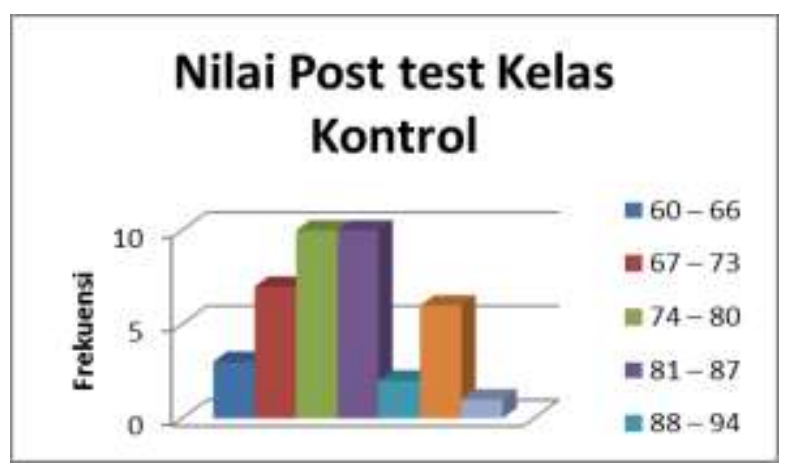

Gambar 5. Histogram nilai post test kelas control

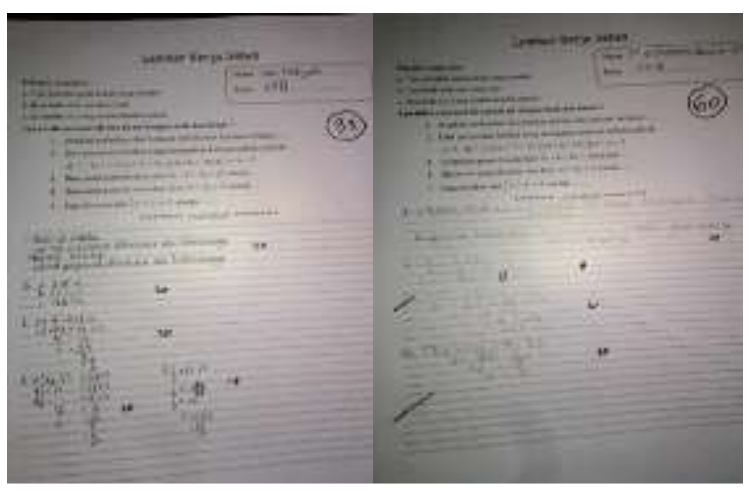

Gambar 6. Nilai Post test tertinggi dan terendah kelas kontrol

Uji validitas Uji validitas dilakukan pada seluruh pernyataan dalam intrumen dengan cara mengkorelasikan skor tiap pertanyaan dengan skor total. Untuk menentukan validitas masing-masing variabel adalah dengan melihat tabel $r$ product moment $\left(r_{x y}\right)$, dengan 
berdasarkan taraf signifikansi $(\alpha) 5 \%$ dan $\mathrm{db}=32-2=30$ yaitu 0,361 .Jika nilai $\mathrm{r}_{\mathrm{xy}}<\mathrm{t}_{\text {tabel }}$ maka dikatakan tidak valid dan jika $r_{x y}>r$ tabel maka dikatakan valid. Teknik korelasi yang digunakan adalah korelasi Product Moment.

Hasil uji validitas terhadap skor-skor variabel adalah sebagai berikut;

\section{Kelas Eksperimen}

\begin{tabular}{cccc}
\hline Variabel & r hitung & $\begin{array}{r}\mathrm{r}_{\text {tabel }} 5 \%(\mathrm{db}=32-2= \\
0,361)\end{array}$ & Interpretasi \\
& \multicolumn{3}{c}{ Post test Kelas Eksperimen } \\
\hline 1 & 0,573 & 0,361 & Valid \\
\hline 2 & 0,676 & 0,361 & Valid \\
\hline 3 & 0,586 & 0,361 & Valid \\
\hline 4 & 0,715 & 0,361 & Valid \\
\hline 5 & 0,584 & 0,361 & Valid
\end{tabular}

\section{Kelas Kontrol}

\begin{tabular}{lll}
\hline rhitung & $\mathrm{r}_{\text {tabel }} 5 \%$ & Interpretasi
\end{tabular}

$$
(\mathrm{db}=32-2=0,361)
$$

Post test Kelas Kontrol

\begin{tabular}{|c|c|c|}
\hline 0,390 & 0,361 & Valid \\
\hline 0,658 & 0,361 & Valid \\
\hline 0,743 & 0,361 & Valid \\
\hline 0,695 & 0,361 & Valid \\
\hline 0,590 & 0,361 & Valid \\
\hline
\end{tabular}

keseluruhan mencapai derajad valid.Karena $r$ hitung dari setiap butir soal lebih besar dari pada $r$ tabel $(0,361)$.

Uji reliabilitas bertujuan untuk mengukur tingkat kekonsistenan instrumen tes hasil belajar. Artinya yaitu sejauh mana suatu alat pengukur dapat dipercaya atau diandalkan dan tetap konsisten jika dilakukan dua kali atau lebih pada kelompok yang sama dengan alat ukur yang sama. Pengujian Cronbach Alpha digunakan untuk menguji tingkat kendalan (reliability) dari masing-masing tes hasil beljar kelas eksperimen maupun kelas kontrol. Suatu intrumen tes dikatakan reliabel jika memberikan nilai $\alpha$ lebih dari $(0,60)$, dan jika nilai $\alpha$ kurang dari $(0,60)$ maka variabel tersebut tidak reliabel. Adapun secara singkat hasil uji reliabilitas ditunjukkan dalam tabel berikut 


\begin{tabular}{lccc}
\hline Kelas & Alpha Cronbach & $\begin{array}{c}\text { Batas } \\
\text { Minimum }\end{array}$ & Interpretasi \\
\hline Eksperimen & 0,600 & 0,60 & Reliabel \\
\hline Kontrol & 0,604 & 0,60 & Reliabel \\
\hline
\end{tabular}

Dari perhitungan Alpha Cronbach tersebut hasil uji reliabilitas yang disajikan dalam tabel di atas menyatakan bahwa reliable karena semua variabel mempunyai nilai Alpha Cronbach di atas 0,600. Dengan demikian data penelitian bersifat layak digunakan untuk pengujian hipotesis penelitian. Pengujian hipotesis menggunakan t-test. Karena jumlah sampel antara kelas eksperimen dan kelas kontrol sama maka model t-test yang digunakan yaitu Separated varian. Keputusan diterima atau ditolaknya hipotesis berdasarkan tingkat signifikansi yang ditetapkan yaitu $5 \%$. Menentukan hipotesis yaitu sebagai berikut;

$\mathrm{H}_{\mathrm{a}}=$ Ada perbedaan yang signifikan antara penggunaa alat peraga papan persamaan papan persamaan linier satu variabel (PLSV) terhadap hasil belajar siswa pada materi sistem persamaan linier satu variabel.

$\mathrm{H}_{0}=$ Tidak ada perbedaan yang signifikan antara penggunaa alat peraga papan persamaan papan persamaan linier satu variabel (PLSV) terhadap hasil belajar siswa pada materi sistem persamaan linier satu variabel.

Penggunaan alat peraga dalam pembelajaran matematika merupakan upaya menjembatani pola berpikir siswa masih dalam tahap konkret dengan objek kajian matematika yang bersifat abstrak (Imas, 2017). Alat peraga juga mampu membuat membuat pembelajaran lebih menarik sehingga menumbuhkan motivasi belajar siswa dan bahan pembelajaran akan lebih jelas sehingga lebih mudah dipahami.

Dari hasil analisis data tes diperoleh kesimpulan bahwa hasil belajar matematika siswa pada materi sistem persamaan linier satu variabel diajar dengan menggunakan alat peraga papan persmaan linier satu variabel (PLSV) lebih baik daripada siswa yang diajar tanpa alat peraga.

Hal ini dapat dilihat pada nilai rata-rata post test pada kelas eksperimen yaitu 82,5625 dan rata-rata post test pada kelas kontrol kontrol yaitu78,25. Dimana nilai rata-rata kelas eksperimen lebih besar dibanding rata-rata kelas kontrol dan diperoleh $t$ hitung 2,088. Dengan $\mathrm{dk}=\mathrm{n}_{1}+\mathrm{n}_{2}-2=32+32-2=62$ dan taraf kesalahan 5\%, maka harga $\mathrm{t}_{\text {tabel }}=2,000$. Karena $\mathrm{t}$ hitung $>\mathrm{t}$ tabel $(2,088>2,000)$ dengan demikian $\mathrm{H} 0$ ditolak dan Ha diterima. Kesimpulannya Ada perbedaan yang signifikan antara penggunaa alat peraga papan persamaan papan 
persamaan linier satu variabel (PLSV) terhadap hasil belajar siswa pada materi sistem persamaan linier satu variabel.

\section{KESIMPULAN}

Berdasarkan tujuan penelitian dan pembahasan yang telah dilakukan mengenai pengaruh penggunaan alat peraga papan persamaan linier satu variabel (PLSV) terhadap hasil belajar matematika siswa pada materi sistem persamaan linier satu variabel di SMP Negeri 2 Panji Tahun Pelajaran 2019/2020 terbukti memberikan pengaruh terhadap hasil belajar matematika siswa pada materi sistem persamaan linier satu variabel. Hal ini ditunjukkan dari hasil uji hipotesis post testyang menyatakan nilai $\mathrm{T}$ hitung $>\mathrm{T}$ tabel $(2,088>2,000)$ pada taraf signifikansi $5 \%$ atau $(\alpha=0,05)$. Selain itu rata-rata nilai post test menunjukkan bahwa kelas eksperimen lebih tinggi dibandingkan dengan kelas kontrol. Perolehan nilai rata-rata post test kelas eksperimen sebesar 82,5625 sedangkan rata-rata kelas kontrol sebesar 78,25.

\section{DAFTAR PUSTAKA}

Annisah, S. 2014. "Alat Peraga Pembelajaran Matematika”. Jurnal Tarbawiyah. Volume 10 Nomor 1 Edisi Januari- Juni 2014.

Binangun, H.H..and Hakim, R.A. 2016. "Pengaruh Penggunaan Alat Peraga Jam Sudut Terhadap Hasil Belajar Matematika".Jurnal JKPM. Volume 1 No. 2 Juni 2016.

Diah, N.S.B. 2014.Strategi Kebut Semalam Matematika SMP. Yogyakarta : Penerbit Cakrawala.

Dian, M. 2014. "Perbandingan Metode Diskusi dan Demosntrasi Terhadap Hasil Belajar Matematika Pokok Bahasan Bangun Ruang“.Jurnal PHYTAGORAS. Volume.03 No. 2 Bulan tidak diterbitkan 2014.

Habibah, M 2013."Pengaruh Penggunaaan Alat Peraga Model Segitiga Pada Pembelajaran Bidang Datar Terhadap Hasil Belajar Siswa".Jurnal Mathematics Education Learning And Teaching. Volume 2 No. 1 Bulan tidak diterbitkan 2013.

Husmul dkk, 2015."Pengaruh Penggunaan Media Alat Peraga Terhadap Hasil Belajar Siswa pada Materi Sistem Peredaran Darah Kelas VIII SMP Negeri 2 Bulukumba”.Jurnal Sainsmat. Volume 04 No.1 Maret 2015.

Ibrahim, R. And Syaodih, N. 2010. Perencanaan Pengajaran. Jakarta : Penerbit Rineka Cipta.

Ibrahim, 2017.'Perpaduan Model Pembelajaran Aktif Konvensional (Ceramah) Dengan Cooperatif (Make- A Match) Untuk Meningkatkan Hasil Belajar Pendidikan Kewarganegaraan".Jurnal Pendidikan Sosial, Sains, dan Humaniora. Volume 03 No. 2 Juni 2017. 
Jamilah, S. and Akbar, O.R. 2016.“Pengaruh Penggunaan Alat Peraga AEM (Algebraic Experience Materials) Terhadap Keterampilan Berpikir Kreatif Siswa Pokok Bahasan Operasi Aljabar".Jurnal Eduma. Volume 5 No. 1 Juli 2016.

Jauhar, M. 2011. Implementasi PAIKEM dari Behavioristik Sampai Kontruktivistik.Jakarta : Penerbit Prestasi Pustaka.

Indrawan.R. dan Yaniawati.P.2014. Metodologi Penelitian Kuantitatif,Kualitatif, dan Campuran untuk Manjement,Pembangunan, dan Pendidikan. Bandung: Refika ADITAMA.

Lastrijanah. 2017. "Pengaruh Penggunaan Media Pembelajaran Geoboard Terhadap Hasil Belajar Siswa. Jurnal Didaktika Tauhidi. Volume 4 No. 2 Oktober 2017.

Masturoh, I. and Khaerani. 2017. "Pengaruh Penggunaan Alat Peraga Geoboard Terhadap Hasil Belajar Siswa Pada Pokok Bahasan Geometri”. Jurnal Primary. Volume 09 No. 02 (Juli-Desember) 2017.

Mustadi dkk. 2017. "Perbandingan Hasil Belajar Matematika Dengan Menggunakan Metode Pembelajaran Make A Match Dan Scramble Pada Peserta Didik Kelas IV SD Inpres Tanah Kareng". Jurnal Pendidikan Matematika dan Pembelajaran.Volume 5 No. 1 Juni 2017.

Nella, E. 2014.“ Perbandingan Pembelajaran Konvensional dan Pembelajaran Berbasis Masalah terhadap Titik Jenuh Siswa Maupun Hasil Belajar Siswa dalam Pembelajaran Matematika”. Jurnal Educatio Vitae.Volume 01 No. 12014.

Nursuprianah, I. and Ani. 2010. "Pengaruh Penggunaan Alat Peraga Lingkaran Terhadap Hasil Belajar Siswa Kelas VIII Pada Pembelajaran Keliling Dan Luas Lingkaran”. Jurnal Eduma. Volume 02 No. 1 Juni 2010.

Setyowati, N. 2016."Penggunaan Alat Peraga untuk Meningkatkan Hasil Belajar dan Keaktifan Siswa pada Materi Peluang”.Jurnal Kreano. Volume 7 No. 1 Juni 2016

Simanulang, J. 2013. 'Pengembangan Bahan Ajar Materi Himpunan Konteks Laskas Pelangi Dengan Pendekatan Pendidikan Matematika Realistik Indonesia (PMRI) Kelas VII Sekolah Menengah Pertama". Jurnal Pendidikan Matematika. Volume 2 No. 2 Juli 2013.

Sugiyono, 2014.Metode Penelitian Kuantitatif Kualitatif Dan $R \&$ D.Bandung : Penerbit Alfabeta.

Susanto, A. 2013.Teori Belajar dan Pembelajaran Di Sekolah Dasar.Jakarta : Penerbit Kencana.

Suharmanto. 2014. "Pengembangan Media Pembelajaran Papan Hitung Pembagian Pada Mata Pelajaran Matematika Sekolah Dasar Kelas 2". Jurnal Tekhnologi Pendidikan. Desember2016 
Suwardi. 2014. "Pengaruh Penggunaan Alat Peraga terhadap Hasil Pembelajaran Matematika pada Anak Usia Dini”. Jurnal AL-AZHAR INDONESIA SERI HUMANIORA. Volume 